\title{
Kombinasi Senam Mata dan Pemberian Kencur Dalam Menurunkan Tingkat Nyeri Mata Lelah Pada Penjahit
}

\author{
Nurrohmah $^{1}$, Fajarina Lathu Asmarani ${ }^{2}$, Adi Sucipto ${ }^{3 *}$ \\ ${ }^{1,2,3}$ Fakultas Ilmu Kesehatan, Universitas Respati, Yogyakarta \\ *Email: adisucipto@respati.ac.id
}

\begin{abstract}
Background: Eye fatigue is often referred to as eye strain or asthenopia. Eye fatigue can be caused by work that requires high focus such as sewing. One of the symptoms of eye fatigue is eye pain. The World Health Organization (WHO) records that the incidence of asthenopia (tired eyes) in the world is an average of $75 \%$ per year. The purpose of this study is to determine the effect of a combination therapy between eye exercise and giving kencur (aromatic ginger or Kaempferia galanga) on the pain level of eye fatigue. Methods: This is a quasi-experimental research design with pretest and posttest nonequivalent control group. The research samples were selected using a Non-Probability Sampling technique with a consecutive sampling method. The number of samples selected was 36, they were divided into the experiment group and the control group. Therapy is given once. Bivariate analysis was performed using Wilcoxon test, paired t-test and independent t-test. The research instrument used was the NRS pain scale. Results: The experiment group's pre-posttest pain scales were 5.06 and 2.78. The control group's preposttest pain scales were 4.50 and 4.00. The bivariate test results of the pre-posttest pain scale of the experiment group and the control group showed p values $=0.000$ and 0.001 . The results of the bivariate test on the posttest between the experimental group and the control group showed p value $=0.028$. Conclusion: Combination of eye exercise and giving kencur has been scientifically proven to reduce eye fatigue better than just eye exercise.
\end{abstract}

Keywords: eye exercise, eye fatigue pain, kencur

\section{PENDAHULUAN}

Mata merupakan salah satu panca indera yang berperan penting bagi manusia dalam melakukan aktivitas sehari-hari. Menurut LeMone, Burke \& Bauldoff (2011) mata merupakan struktur kompleks yang mengandung $70 \%$ reseptor sensori tubuh. Mata terdiri dari beberapa bagian, sehingga mata dapat bekerja sesuai dengan fungsinya (Wirgunatha \& Adiputra, 2019).

Fungsi mata yang berhubungan dengan kegiatan menjahit yaitu melakukan akomodasi, yaitu kemampuan mata untuk mengubah daya bias agar mendapatkan fokus pada objek dekat dengan baik. Saat mata digunakan untuk bekerja secara berlebihan, terutama pada kegiatan yang membutuhkan konsentrasi tinggi, maka dapat mengakibatkan mata lelah atau astenopia (Prayoga, 2014;
Elfananda, Widada \& Sasmiyanto, 2015). Ketegangan otot-otot pengakomodasi (otot-otot siliar) semakin meningkat sehingga terjadi peningkatan asam laktat dan menyebabkan terjadinya kelelahan mata, stres pada retina dapat terjadi bila kontras yang berlebihan dalam lapang penglihatan dan waktu melihat yang cukup lama (Ilyas, 2010).

World Health Organitation (WHO) mencatat angka kejadian astenopia (kelelahan mata) di dunia rata-rata $75 \%$ per tahun (Sya'ban \& Riski, 2014). Astenopia dapat menyebabkan penurunan kemampuan akomodasi mata sehingga berakibat pada severe low vision. Berdasarkan Riskesdas (2013) di Indonesia prevalensi severe low vision pada usia produktif mencapai $1,49 \%$ dari total populasi. Jumlah penderita severe low vision terbanyak yaitu provinsi Jawa 
Timur dengan jumlah 352.829 jiwa, peringkat dua adalah provinsi Jawa Tengah dengan jumlah penderita severe low vision sebanyak 329.428 jiwa. Hasil penelitian sebelumnya menunjukkan bahwa $95,3 \%$ orang yang melakukan kegiatan menjahit mengalami mata lelah, $39,5 \%$ diantaranya mengalami mata lelah dengan gejala yang timbul yaitu nyeri mata (Wirgunatha \& Adiputra, 2019).

Di dalam mata terdapat otot yang berperan untuk mengendalikan pergerakan mata, yaitu rektus lateral, rektus media, rektus superior, rektus inferior, oblik inferior, dan oblik superior (LeMone, Burke \& Bauldoff, 2011). Ketika otototot tersebut dipaksa untuk bekerja keras maka dapat mengakibatkan mata menjadi lelah. Gejala nyeri mata akan terasa setelah beberapa jam bekerja.

Secara farmakologi, penatalaksanaan untuk nyeri pada mata yaitu dengan obat tetes mata (lubricating eye drop), dimana kandungan obat tetes mata tersebut yaitu antibiotik, antiinflamasi, analgesik, dan senyawa lainnya (Diah, 2009; Elfananda, Widada \& Sasmiyanto, 2015). Ketika diabsorpsi pada aliran darah, obat tetes tersebut dapat menimbulkan efek samping pada bagian tubuh lainnya (James, 2005; Elfananda, Widada \& Sasmiyanto, 2015). Efek samping yang muncul dapat berupa penglihatan kabur, atrofi saraf optik, demam, dll (Ilyas, 2010).

Secara non farmakologi, nyeri mata lelah dapat diatasi dengan senam mata (eye exercises), blink (kedipan mata), terapi madu, dan kencur. Lestari (2016) mengungkapkan bahwa kencur dapat digunakan untuk mengatasi mata pegal atau nyeri mata. Senam mata merupakan teknik yang digunakan agar bola mata terbiasa lentur dan bergerak sesuai dengan jangkauan mata, serta membuat otot mata dan sekitarnya menjadi elastis dan kuat (Hariadi, 2014; Arisandi, Utami \& Novayelinda, 2018). Sedangkan kencur mengandung senyawa ethyl-pmethoxycinnamate yang bersifat sebagai analgesik (Silalahi, 2019). Cara penggunaannya yaitu dengan membelah kencur menjadi dua bagian, kemudian menggosokkan bagian sisi yang masih basah pada pelupuk mata (Herbie, 2015). Reaksi panas yang ditimbulkan dapat memperlancar aliran darah sehingga mengurangi penumpukan asam laktat. Penelitian ini bertujuan untuk mengetahui efek kombinasi senam mata dan pemberian kencur dalam menurunkan tingkat nyeri mata lelah pada penjahit.

\section{METODE PENELITIAN}

Penelitian ini adalah penelitian eksperimen semu (quasi experimental) dengan desain penelitian pre test dan post test dengan kelompok kontrol (pre test and post test non equivalent control group). Penelitian dilaksanakan pada tanggal 24-27 Juni 2020 di daerah Kabupaten Magelang. Populasi penelitian ini adalah seluruh penjahit di daerah Kabupaten Magelang. Sampel dalam penelitian ini adalah penjahit home industri di Kabupaten Magelang dengan kriteria sampel yaitu menderita nyeri mata lelah, bersedia menjadi responden, tidak mengalami sakit mata seperti infeksi atau luka, dan tidak melakukan tanam bulu mata.

Jumlah sampel yaitu 36 orang yang terbagi menjadi kelompok eksperimen (senam mata dan pemberian kencur) dan kelompok kontrol (senam mata). Pengambilan sampel menggunakan teknik consecutive sampling. Peneliti mendatangi responden di rumah masing-masing. 
Responden diberikan terapi senam mata dan pemberian kencur sebanyak satu kali. Waktu untuk melakukan senam mata yaitu \pm 10 menit, dilanjutkan dengan pemberian kencur. Skala nyeri diukur menggunakan
Numeric Rating Scale (NRS). Nyeri diukur sebelum dan sesudah terapi. Analisa data dilakukan menggunakan $t$ test independent sample.

\section{HASIL PENELITIAN}

Tabel 1. Distribusi Frekuensi Responden Berdasarkan Data Demografi

\begin{tabular}{|c|c|c|c|c|c|c|}
\hline \multirow[t]{2}{*}{ Karakteristik } & \multicolumn{2}{|c|}{$\begin{array}{c}\text { Kelompok } \\
\text { Eksperimen }(n=18)\end{array}$} & \multicolumn{2}{|c|}{$\begin{array}{c}\text { Kelompok Kontrol } \\
(n=18)\end{array}$} & \multicolumn{2}{|c|}{ Total } \\
\hline & $\mathbf{n}$ & $\%$ & $\mathbf{n}$ & $\%$ & $\mathbf{n}$ & $\%$ \\
\hline \multicolumn{7}{|l|}{ Jenis Kelamin } \\
\hline Laki-laki & 2 & 11.1 & 0 & 0 & 2 & 5.6 \\
\hline Perempuan & 16 & 88.9 & 18 & 100.0 & 34 & 94.4 \\
\hline Total & 18 & 100.0 & 18 & 100.0 & 36 & 100.0 \\
\hline \multicolumn{7}{|l|}{ Usia } \\
\hline 17-25 tahun & 1 & 5.6 & 5 & 27.8 & 6 & 16.7 \\
\hline 26-35 tahun & 4 & 22.2 & 5 & 27.8 & 9 & 25.0 \\
\hline 36-45 tahun & 11 & 61.1 & 4 & 22.2 & 15 & 41.7 \\
\hline 46-55 tahun & 1 & 5.6 & 2 & 11.1 & 3 & 8.3 \\
\hline 56-65 tahun & 1 & 5.6 & 2 & 11.1 & 3 & 8.3 \\
\hline Total & 18 & 100.0 & 18 & 100.0 & 36 & 100.0 \\
\hline $\begin{array}{lc} & \text { Pada tabel } \\
\text { dari data } & \text { pene } \\
\text { distribusi } & \text { resp } \\
\text { kelamin paling b }\end{array}$ & $\begin{array}{l}1 \text { dap } \\
\text { litian } \\
\text { nden } \\
\text { nyak y: }\end{array}$ & $\begin{array}{l}\text { ihat bahy } \\
\text { diperole } \\
\text { arut jer } \\
\text { nis kelam }\end{array}$ & $\begin{array}{l}\text { pere } \\
\text { Berd } \\
\text { terba } \\
\text { tahur }\end{array}$ & $\begin{array}{l}\text { n deng } \\
\text { an us } \\
\text { adalah } \\
\text { gan tota }\end{array}$ & $\begin{array}{r}\text { total } \\
\text { dil } \\
\text { wasa } \\
(41.7\end{array}$ & $\begin{array}{rr} & (94.4 \%) . \\
\text { ii } & \text { usia } \\
& (36-45\end{array}$ \\
\hline
\end{tabular}

Tabel 2. Distribusi Frekuensi Faktor Penyebab Nyeri Mata Lelah Pada Responden

\begin{tabular}{lcccc}
\hline \multirow{2}{*}{ Karakteristik } & \multicolumn{2}{c}{$\begin{array}{c}\text { Kelompok Eksperimen } \\
(\mathbf{n = 1 8})\end{array}$} & \multicolumn{2}{c}{$\begin{array}{c}\text { Kelompok Kontrol } \\
(\mathbf{n = 1 8})\end{array}$} \\
\cline { 2 - 5 } & $\mathbf{n}$ & $\mathbf{\%}$ & $\mathbf{n}$ & $\mathbf{\%}$ \\
\hline Mata Minus & 6 & 33.3 & 7 & 38.9 \\
Ya & 12 & 66.7 & 11 & 61.1 \\
Tidak & $\mathbf{1 8}$ & $\mathbf{1 0 0 . 0}$ & $\mathbf{1 8}$ & $\mathbf{1 0 0 . 0}$ \\
\hline Total & & & & \\
\hline Jarak Pandang & 6 & 33.3 & 3 & 16.7 \\
$<30 \mathrm{~cm}$ & 7 & 38.9 & 6 & 33.3 \\
$30 \mathrm{~cm}$ & 5 & 27.8 & 9 & 50.0 \\
$>30 \mathrm{~cm}$ & $\mathbf{1 8}$ & $\mathbf{1 0 0 . 0}$ & $\mathbf{1 8}$ & $\mathbf{1 0 0 . 0}$ \\
\hline Total & & & & \\
\hline Penerangan & 0 & 0 & 0 & 0 \\
Redup & 18 & 100.0 & 18 & 100.0 \\
Terang & & &
\end{tabular}




\begin{tabular}{lcccc} 
Terlalu Terang & 0 & 0 & 0 & 0 \\
\hline Total & $\mathbf{1 8}$ & $\mathbf{1 0 0 . 0}$ & $\mathbf{1 8}$ & $\mathbf{1 0 0 . 0}$ \\
\hline Durasi Kerja & & & & \\
$<8$ jam & 10 & 55.6 & 14 & 77.8 \\
$\geq 8$ jam & 8 & 44.4 & 4 & 22.2 \\
\hline Total & $\mathbf{1 8}$ & $\mathbf{1 0 0 . 0}$ & $\mathbf{1 8}$ & $\mathbf{1 0 0 . 0}$ \\
\hline
\end{tabular}

Pada tabel 2 dapat dilihat bahwa responden yang menderita mata minus pada kelompok eksperimen yaitu sebanyak 6 orang (33.3\%) sedangkan pada kelompok kontrol yaitu 7 orang (38.9\%). Berdasarkan jarak pandang, sebagian besar responden masih bekerja dengan jarak pandang yang kurang tepat, yaitu pada kelompok eksperimen 6 orang (33.3\%) pada jarak $<30 \mathrm{~cm}$ dan 5 orang $(27.8 \%)$ pada jarak $>30 \mathrm{~cm}$, sedangkan pada kelompok kontrol sebagian besar bekerja dengan jarak pandang $<30 \mathrm{~cm}$ yaitu sebanyak 9 orang $(50 \%)$. Berdasarkan penerangan, seluruh responden pada kedua kelompok yaitu 36 orang $(100 \%)$ bekerja dengan penerangan cukup terang. Pada kelompok eksperimen sebanyak 8 orang (44.4\%) bekerja selama $>8$ jam per hari, sedangkan pada kelompok kontrol hanya 4 orang $(22.2 \%)$ bekerja selama $>8$ jam per hari.

Tabel 3. Mean Tingkat Nyeri Mata Lelah Pre Test dan Post Test Kelompok Eksperimen

\begin{tabular}{lccccc}
\hline $\begin{array}{l}\text { Kelompok } \\
\text { Eksperimen }\end{array}$ & N & Mean & $\begin{array}{c}\text { Standar } \\
\text { deviasi }\end{array}$ & Min. & Maks. \\
\hline Pre Test & 18 & 5.06 & 1.434 & 1 & 8 \\
\hline Post Test & 18 & 2.78 & 1.396 & 0 & 6 \\
\hline
\end{tabular}

Pada tabel 3 dapat dilihat nilai skor tingkat nyeri mata lelah sebelum diberikan intervensi senam mata dan pemberian kencur yaitu 5.06 dan nilai nilai skor tingkat nyeri mata lelah sesudah diberikan intervensi yaitu 2.78. Rentang skor tingkat nyeri mata lelah pre test yaitu minimum 1 dan maksimum 8 , serta pada post test terdapat penurunan skor tingkat nyeri mata lelah yaitu minimum 0 dan maksimum 6 .

Tabel 4. Mean Tingkat Nyeri Mata Lelah Pre Test dan Post Test Kelompok Kontrol

\begin{tabular}{llcccc}
\hline $\begin{array}{l}\text { Kelompok } \\
\text { Kontrol }\end{array}$ & $\mathbf{N}$ & Mean & $\begin{array}{l}\text { Standar } \\
\text { deviasi }\end{array}$ & Min. & Maks. \\
\hline Pre Test & 18 & 4.50 & 1.465 & 2 & 8 \\
\hline Post Test & 18 & 4.00 & 1.782 & 1 & 8 \\
\hline \multicolumn{2}{c}{ Pada tabel 4 dapat dilihat nilai skor } & nyeri mata lelah pre test yaitu minimum 2 \\
tingkat nyeri mata lelah pada kelompok & $\begin{array}{l}\text { dan maksimum 8, serta pada post test } \\
\text { kontrol sebelum diberikan intervensi } \\
\text { senam mata yaitu 4.50 dan nilai nilai skor } \\
\text { tingkat nyeri mata lelah sesudah diberikan }\end{array}$ & $\begin{array}{l}\text { mata lelah yaitu minimum } 1 \text { dan } \\
\text { maksimum 8. }\end{array}$
\end{tabular}
intervensi yaitu 4.00. Rentang skor tingkat 
Tabel 5. Perbedaan Tingkat Nyeri Mata Lelah Pre Test dan Post Test Kelompok Eksperimen

\begin{tabular}{lcccc}
\hline $\begin{array}{l}\text { Kelompok } \\
\text { Eksperimen }\end{array}$ & N & Mean & Selisih mean & p value \\
\cline { 1 - 3 } Pre test & 18 & 5.06 & 2.28 & 0.000 \\
\hline Post test & 18 & 2.78 & & \\
\hline
\end{tabular}

Berdasarkan tabel 5 dapat dilihat wilcoxon diperoleh $p$ value $(0.000)<$ rata-rata skor tingkat nyeri mata lelah (0.05), maka dapat disimpulkan bahwa pada kelompok eksperimen sebelum ada perbedaan skor tingkat nyeri mata diberikan intervensi senam mata dan lelah sebelum dan sesudah diberikan pemberian kencur yaitu 5.06 sedangkan intervensi berupa senam mata dan setelah dilakukan intervensi yaitu 2.78, pemberian kencur pada kelompok yang berarti mengalami penurunan dengan eksperimen.

beda mean 2.28. Hasil uji statistik

Tabel 6. Perbedaan Tingkat Nyeri Mata Lelah Pre Test dan Post Test Kelompok Kontrol

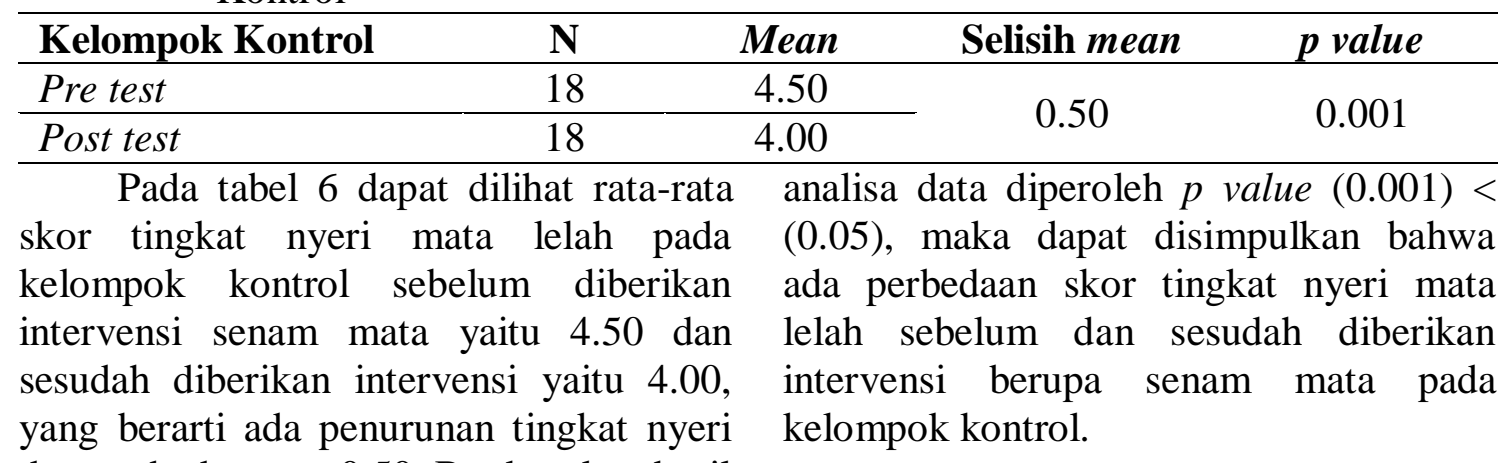
dengan beda mean 0.50. Berdasarkan hasil

Tabel 7. Perbedaan Rata-Rata Tingkat Nyeri Mata Lelah Sesudah Intervensi Pada Kelompok Eksperimen dan Kontrol

\begin{tabular}{lccc}
\hline Kelompok & $\mathbf{N}$ & Mean & p value \\
\hline Eksperimen & 18 & 2.78 & 0.028 \\
\hline Kontrol & 18 & 4.00 & \\
\hline
\end{tabular}

Berdasarkan tabel 7 di atas, hasil uji statistik $t$-test independent pada kelompok post test eksperimen dan kontrol diperoleh $p$ value $(0.028)<(0.05)$, maka dapat disimpulkan bahwa ada perbedaan yang signifikan rata-rata skor tingkat nyeri mata lelah setelah diberikan intervensi antara kelompok eksperimen dan kelompok kontrol.

\section{PEMBAHASAN}

Dari hasil pengukuran nyeri mata lelah sebelum intervensi yaitu didapat mean pada kelompok eksperimen sebesar 5.06 dan kelompok kontrol sebesar 4.50 yang berarti responden pada kedua kelompok mengalami nyeri sedang. Nyeri mata lelah dapat dipengaruhi oleh faktor usia. Berdasarkan karakteristik usia terhadap nyeri mata lelah, pada tabel 1 dapat dilihat bahwa pekerja yang paling 
banyak menderita nyeri mata lelah yaitu pada rentang usia 36-45 tahun (dewasa akhir) sebanyak 15 (41.7\%). Pada usia tersebut, mulai terjadi penurunan fungsi pada sistem tubuh tak terkecuali pada indera penglihatan. Dengan bertambahnya usia terjadi penurunan pada daya akomodasi mata (Fadlillah, 2013; Irma, Lestari \& Kurniawan, 2019). Kelainan akomodasi biasanya terjadi pada usia 40 tahun karena lensa mata menjadi kaku seiring bertambahnya usia sehingga kemampuan lensa mata untuk melakukan akomodasi terjadi penurunan. Kelainan akomodasi dapat menimbulkan gejala mata lelah meliputi mata berair, nyeri pada mata dan terasa perih (Djoni, 2016; Irma, Lestari \& Kurniawan, 2019).

Pada tabel 2 dapat dilihat bahwa responden yang menderita mata minus pada kelompok eksperimen yaitu sebanyak 6 orang $(33.3 \%)$ sedangkan pada kelompok kontrol yaitu 7 orang (38.9\%) sehingga pada saat bekerja menggunakan kaca mata. Beberapa pekerja bahkan tidak menggunakan kaca mata, sehingga justru semakin membebani kerja pada mata. Pada saat seseorang bekerja menggunakan kaca mata secara terus menerus, dapat mengakibatkan munculnya gejala kelelahan mata salah satunya yaitu nyeri mata lelah. Menurut Ilyas (2010) kelainan refraksi pada mata minus terjadi akibat ketidakseimbangan pada sistem optik pada mata sehingga menghasilkan bayangan kabur. Kelainan refraksi sangat berpotensi terhadap terjadinya kelelahan mata karena daya akomodasi pada mata yang menurun.

Sebagian besar responden masih bekerja dengan jarak pandang yang kurang tepat, yaitu pada kelompok eksperimen 6 orang $(33.3 \%)$ bekerja pada jarak $<30 \mathrm{~cm}$ dan 5 orang (27.8\%) bekerja pada jarak $>30 \mathrm{~cm}$, sedangkan pada kelompok kontrol sebagian besar bekerja dengan jarak pandang $<30 \mathrm{~cm}$ yaitu sebanyak 9 orang $(50 \%)$. Lebih banyak pekerja yang tidak menerapkan posisi yang ergonomis pada saat bekerja. Pada saat seseorang melihat objek pada jarak yang terlalu jauh atau terlalu dekat dengan fokus yang tinggi seperti pada saat menjahit, dapat menyebabkan mata menjadi lelah dan pegal. Hasil penelitian ini sesuai dengan hasil penelitian Rachmah et al. (2018) yang menunjukkan bahwa pekerja dengan jarak objek kerja $<30 \mathrm{~cm}$ atau terlalu dekat berisiko $15 \mathrm{kali}$ mengalami kelelahan mata. Pada individu dewasa muda dengan penglihatan normal, titik dekat penglihatan biasanya 20 sampai $25 \mathrm{~cm}$ (LeMone, Burke \& Bauldoff, 2011).

Nyeri mata lelah juga dapat disebabkan karena lama waktu kerja yang melebihi batas normal. Pada kelompok eksperimen sebanyak 8 orang (44.4\%) bekerja selama $>8$ jam per hari, sedangkan pada kelompok kontrol hanya 4 orang $(22.2 \%)$ bekerja selama $>8$ jam per hari. Nyeri mata lelah yang dirasakan diakibatkan oleh lama waktu kerja yang tidak efektif. Mata dipaksa untuk bekerja dalam waktu yang sangat lama untuk melihat objek kecil. Menurut Irma, Lestari \& Kurniawan (2019) lamanya seseorang bekerja setiap hari umumnya 6 hingga 8 jam. Pekerjaan yang memerlukan penglihatan dengan jarak dekat menyebabkan mata untuk melakukan akomodasi. Ketika mata melakukan akomodasi secara terus-menerus dalam waktu yang lama bahkan hingga berjamjam, dapat menyebabkan tegang pada otot mata sehingga menyebabkan kelelahan mata (Rachmah et al., 2018).

Berdasarkan tabel 5 skala nyeri pada post test kelompok eksperimen yang 
diberikan intervensi senam mata dan pemberian kencur yaitu 2.78 (nyeri ringan). Beda mean antara pre test dan post test yaitu 2.28. Hasil uji bivariat menggunakan uji wilcoxon pada kelompok eksperimen diperoleh $p$ value (0.000) dimana $p$ value lebih kecil dari $\alpha$ (0.05) yang berarti bahwa ada perbedaan sebelum dan sesudah intervensi kombinasi senam mata dan pemberian kencur pada tingkat nyeri mata lelah. Pada kelompok eksperimen pada tabel 6 terdapat penurunan mean tingkat nyeri mata lelah yaitu sebesar 2.28 karena intervensi yang diberikan berupa kombinasi senam mata dan pemberian kencur. Dua intervensi berbeda yang dikombinasikan dapat berpengaruh lebih efektif dalam menurunkan tingkat nyeri mata lelah pada pekerja yang menjahit. Skala nyeri pada post test kelompok kontrol yang diberikan intervensi senam mata yaitu 4.00 (nyeri sedang). Beda mean antara pre test dan post test yaitu 0.50. Hasil uji bivariat menggunakan uji t-test paired pada kelompok kontrol diperoleh $p$ value (0.001) dimana $p$ value lebih kecil dari $\alpha$ (0.05). Maka dapat disimpulkan bahwa ada perbedaan sebelum dan sesudah intervensi senam mata pada tingkat nyeri mata lelah.

Senam mata dapat membuat mata menjadi lebih terlatih untuk bergerak sehingga mengurangi kekakuan pada otot mata. Sedangkan kencur yang dioleskan pada kelopak mata memberikan efek hangat sampai panas sehingga membuat mata menjadi fresh. Menurut Hariadi, 2014; Arisandi, Utami \& Novayelinda (2018) senam mata merupakan suatu gagasan yang fleksibel karena sangat mudah untuk dilakukan, tidak membutuhkan waktu yang lama, tidak memerlukan tempat khusus serta tidak memerlukan biaya. Senam mata dapat dilakukan dengan posisi berdiri, duduk maupun tidur. Senam mata melatih otototot mata yang bertujuan untuk mengurangi gejala mata lelah. Sedangkan kencur mengandung senyawa ethyl-pmethoxycinnamate yang bersifat sebagai analgesik, untuk menurunkan nyeri atau rasa sakit (Umar et al., 2014).

Hasil uji t-test independent (tabel 7) pada kelompok eksperimen yang diberikan senam mata dan pemberian kencur dengan kelompok kontrol yang hanya diberikan senam mata menunjukkan $p$ value $(0.028)<(0.05)$. Beda mean pada kelompok eksperimen yaitu 2.28, lebih besar dari beda mean kelompok kontrol yaitu 0.50. Hal tersebut menunjukkan bahwa senam mata dan pemberian kencur lebih efektif dibanding hanya dilakukan senam mata. Hal ini disebabkan karena responden melakukan tahapan senam mata dengan tepat serta efek kandungan dari kencur yang dioleskan pada kelopak mata. Sehingga efek yang dihasilkan lebih baik dibandingkan hanya dilakukan senam mata. Maka dapat disimpulkan bahwa ada pengaruh yang signifikan antara pemberian intervensi berupa senam mata dan pemberian kencur terhadap tingkat nyeri mata lelah.

Penelitian ini sejalan dengan penelitian yang dilakukan oleh Judie, Selvakanie \& Uma (2016) yang menunjukkan bahwa terdapat perbedaan sebelum dan sesudah dilakukan senam mata dengan $p$ value $(0.0001)<(0.05)$. Senam mata dapat memperkuat semua otot ekstraokular dan otot siliaris, membantu mengurangi ketegangan mata, membuat otot mata menjadi fleksibel serta mempertahankan ketajaman mata (Hariadi, 2014; Arisandi, Utami \& Novayelinda, 2018). Senam mata juga 
menstimulasi otot-otot mata dengan gerakan-gerakan yang melibatkan otot mata sehingga sirkulasi darah lancar dan mengurangi penumpukan asam laktat sehingga dapat menurunkan nyeri pada mata. Meningkatnya sirkulasi darah sangat memberi dampak yang baik untuk mata karena darah membawa oksigen serta nutrisi untuk sel-sel mata sehingga membuat mata menjadi segar dan meningkatkan ketajaman mata (Gosewade, Drugkar \& Shende, 2016). Beberapa gerakan seperti palming membuat otot-otot mata beristirahat sejenak karena saat gerakan palming mengakibatkan cahaya tidak dapat masuk ke mata dan rasa hangat saat palming juga membuat otot serta saraf mata menjadi rileks (Dhote, 2015). Selain itu, teknik eye massage dapat membantu melancarkan aliran darah pada area mata sehingga banyak oksigen yang terbawa menuju area mata dan membuat mata menjadi lebih rileks kembali

Begitu pula penelitian yang dilakukan oleh Silalahi (2019) yang menyatakan bahwa kencur mengandung senyawa ethyl p-methoxynnamate yang bersifat sebagai analgesik (pereda nyeri). Setelah responden dioleskan kencur pada kelopak matanya, maka muncul efek hangat hingga panas. Secara fisiologis, respon tubuh terhadap panas yaitu vasodilatasi pada pembuluh darah, menurunkan kekentalan darah, menurunkan ketegangan otot, meningkatkan metabolisme aerob pada jaringan, serta meningkatkan permeabilitas kapiler (Potter \& Perry, 2010). Peningkatan metabolism aerob pada jaringan dapat menekan penumpukan asam laktat. Aliran darah yang kaya akan oksigen dapat membuat asam laktat yang menumpuk menjadi mudah larut dalam darah dan mudah dibuang oleh tubuh sehingga menurunkan nyeri. Mekanisme kerja ethyl-p-methoxycinnamate dalam KG hampir sama dengan NSAID, yaitu dengan menghambat enzim COX melalui metabolisme asam arakidonat yang menyebabkan penurunan sintesis prostaglandin. Prostaglandin merupakan mediator inflamasi yang dapat menyebabkan tumor (pembengkakan) dan timbulnya nyeri (Umar et al,. 2012).

Pada penelitian ini, kombinasi senam mata dan kencur lebih menimbulkan efek yang signifikan terhadap nyeri dibandingkan senam mata saja. Gerakan-gerakan senam mata dapat merilekskan otot mata yang tegang. Sedangkan efek panas pada kencur dapat melancarkan peredaran darah sehingga meningkatkan metabolisme aerob dan dapat mengurangi penumpukan asam laktat pada otot mata. Senam mata berpengaruh pada penurunan nyeri mata lelah namun tidak signifikan dibandingkan kombinasi senam mata dan kencur apabila hanya dilakukan satu kali. Berdasarkan hasil penelitian Arisandi, Utami \& Novayelinda (2018) menyatakan bahwa senam mata dapat berpengaruh signifikan apabila dilakukan selama 3 hingga 4 kali.

\section{KESIMPULAN DAN SARAN}

Kombinasi senam mata dan pemberian kencur terbukti secara ilmiah lebih menurunkan nyeri mata lelah dibandingkan hanya senam mata saja. Berdasarkan hal tersebut maka direkomendasikan responden dapat melakukan terapi senam mata dan pemberian kencur secara rutin dalam mengurangi gejala nyeri mata lelah. Peneliti selanjutnya diharapkan dapat mengkombinasikan senam mata dengan tanaman herbal yang lain selain kencur 
atau membandingkan antara senam mata dengan kencur sebagai pereda nyeri (analgesik).

\section{DAFTAR RUJUKAN}

Dhote, S. A. (2015). Eye Exercises An Eyesight Rejuvenation Therapy. World Journal of Pharmaceutical Research, 4(6), 1552-1563.

Elfananda, T., Widada, W., \& Sasmiyanto. (2015). Pengaruh Terapi Madu Terhadap Tingkatan Nyeri Mata Lelah pada Pekerja di Bengkel Las Listrik Kecamatan Patrang Jember.

Gosewade, N., Drugkar, A., \& Shende, V. (2016). Effect of Pranayama and Eye Exercises on Visual Acuity of Medical Students: A Case Control Study. International Journal of Contemporary Medical Research, 3(4), 1133-1136. Retrieved from www.ijcmr.com

Herbie, T. (2015). Kitab Tanaman Berkhasiat Obat. Yogyakarta: Octopus Publishing House.

Ilyas, S. (2010). Ilmu Penyakit Mata (3rd ed.). Jakarta: Balai Penerbit Fakultas Kedokteran Universitas Indonesia.

Irma, I., Lestari, I., \& Kurniawan, A. R. (2019). Faktor yang Berhubungan dengan Keluhan Subjektif Kelelahan Mata pada Pengguna Komputer. Jurnal Ilmiah Kesehatan Pencerah, 8(1), 15-23.

Judie, A., Selvakanie, P., \& Uma, K. (2016). A Study to Assess The Effectiveness of Eye Exercises on
Asthenopic Symptoms And Level of Vision among Information Technology ( IT ) Professionals Working in Selected Settings, Tamil Nadu. Research \& Reviews: Journal of Nursing \& Health Sciences, 2(1), 72-75.

LeMone, P., Burke, K. M., \& Bauldoff, G. (2011). Medical-Surgical Nursing: Critical Thinking in Patien Care (5th ed.). London: Pearson Education.

Lestari, P. (2016). Studi Tanaman Khas Sumatera Utara yang Berkhasiat Obat. Jurnal Farmanesia, 1(1), 1121.

Potter, P. A., \& Perry, A. G. (2010). Fundamental Keperawatan (7th ed.). Jakarta: Salemba Medika.

Putri Arisandi, I., Tri Utami, G., \& Novayelinda, R. (2018). Efektivitas Senam Mata Terhadap Computer Vision Syndrom (CVS). JOM FKp, 5(2), 520-526.

Rachmah, A., Utami, T., Suwondo, A., \& Jayanti, S. (2018). Faktor Risiko yang Berhubungan dengan Kelelahan Mata pada Pekerja Home Industry Batik Tulis Lasem. Jurnal Kesehatan Masyarakat, 6(5), 469475.

Riskesdas. (2013). Laporan Hasil Riset Kesehatan Dasar. Retrieved from www.litbang.depkes.go.id

Silalahi, M. (2019). Kencur (Kaempferia Galanga) dan Bioaktivitasnya. Jurnal Pendidikan Informatika Dan 
Sains, $\quad$ 8(1), $\quad$ 127-142. https://doi.org/10.31571/saintek.v8i 1.1178

Sya'ban, A. R., \& Riski, I. M. R. (2014). Faktor-Faktor yang Berhubungan dengan Gejala Kelelahan Mata (Asstenopia) pada Karyawan Pengguna Komputer Pt.Grapari Telkomsel Kota Kendari. Proseding Seminar Bisnis \& Teknologi, 754768.

Umar, M. I., Asmawi, M. Z., Sadikun, A., Atangwho, I. J., Yam, M. F., Altaf, R., \& Ahmed, A. (2012). Bioactivity-Guided Isolation of Ethyl-p-methoxycinnamate, an Antiinflammatory Constituent, from Kaempferia Galanga L. Extracts. Molecules, 17(7), 8720-8734. https://doi.org/10.3390/molecules17 078720

Umar, M. I., Asmawi, M. Z., Sadikun, A., Majid, A. M. S. A., Al-suede, F. S. R., Hassan, L. E. A., ... Ahamed, M. B. K. (2014). Ethyl- p methoxycinnamate Isolated From Kaempferia Galanga Inhibits Inflammation By Suppressing Interleukin-1, Tumor Necrosis Factor- a, and angiogenesis by blocking Endothelial Functions. CLINICS, 69(02), 134-144. https://doi.org/10.6061/clinics/2014( 02) 10

Wirgunatha, M. W., \& Adiputra, L. M. I. S. H. (2019). Prevalensi dan Gambaran Kelelahan Mata pada Penjahit Garmen Di Kota Denpasar. E-Journal Medika, 8(4). 